\section{Freeze Branding Cattle for Individual Identification ${ }^{1}$}

\section{FLOYD W. POND AND}

H. A. PEARSON

Range Scientist and Principal Range Scientist, Rocky Mountain Forest and Range Experiment Station, 2 Flagstaff, Arizona.

\section{Highlight}

Freeze branding appears to be a good method for marking cattle for individual identification. In three trials, over $80 \%$ of the branded animals developed readable brands, but only $60 \%$ could be identified on Super-8 film exposed from a distance of $5 \mathrm{ft}$ overhead.

A method of permanently marking cattle for identification has long been a problem in range and pasture research. This problem was recently highlighted by the development of a fully automatic weighing devicc which uses an overhead camera to identify the animal being weighed (Martin et al., 1967). Although several picture frames of head, neck, and back were

${ }^{1}$ Received February 4, 1971; accepted for publication February 5, 1971.

${ }^{2}$ Forest Service, U. S. Department of Agriculture, with central headquarters maintained at Fort Collins, in cooperation with Colorado State University; project headquarters is at Flagstaff, in cooperation with Northern Arizona University. Mr. Pearson is now located at Southern Forest Experiment Station, Pineville, Louisiana. taken, identification of individuals from a herd of uniform cattle was virtually impossible without some special mark. Freeze branding numerals on the loin was onc of scveral methods tried for identification purposes.

Freeze branding, a relatively new idea, is appropriate for dark-haired animals. It leaves a permanent brand composed of white hair after the supercold "iron" kills the pigment-producing cells of the hair follicles. Unlike hot branding, freeze branding usually causes little or no damage to hides and, if recognized as a legal mark of ownership, could rcsult in considcrable savings to the hide industry each year. If the "iron" is held in place too long, however, it will produce a hairless brand, and the hide will be damaged (Anonymous, 1970).

Ely and Launchbaugh (1969) reported that $77 \%$ of 300 steers branded in 1968 had legible brands 8 months later. How legible such brands appear on Super-8 film has not been reported. This paper reports methods and equipment for freeze branding as well as direct and film-recorded visibility of brands on yearling and 2-year-old cattle in Arizona.

\section{Equipment and Materials}

Several items are necessary and others are useful in freeze branding:

1. A squeeze chute to restrain animals since the cold "iron" must be held in place for several seconds.

2. Fine-toothed clippers to remove hair and avoid insulation that would prevent adequate freezing.
3. An open can of kcroscne to clean and lubricate clippers.

4. "Irons" of copper alloy. Those used in this study consisted of a set of numerals, 0 through 9 . The 4 -inch numeral was formed of material $3 / 8$-inch wide (rounded face) and $13 / 8$ inches thick. 'The heavy numeral was capable of retaining supercold temperatures for some time, an important factor in branding.

5. An insulated chest of sufficient size to hold all "irons" and enough coolant to cover "irons."

6. Dry ice and coolant (alcohol, gasoline, or other low-freezing-point liquid) or liquid nitrogen to supercool "irons."

7. Sponges or brushes and uncooled coolant to cleanse and wet the clipped branding site.

The above materials and equipment, exclusive of the squeeze chute, cost approximately $\$ 185$.

\section{Methods}

Sufficient methanol to cover the copper alloy irons was placed in the insulated chest, and several small pieces of dry ice were added. The "boiling" action caused by dry ice stopped after about 20 minutes, signifying that the irons were supercooled to about $-90 \mathrm{~F}$. Rechilling of irons after use required about 2 minutes, during which "boiling" was again noticeable.

Once the animal was restrained, hair was closely clipped from the branding site. This clipped area was thoroughly cleansed with a sponge soaked in meth- 


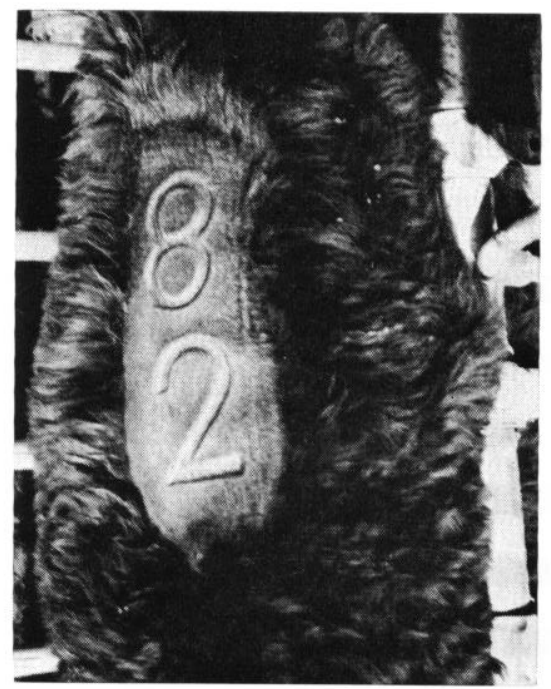

FIG. 1. A frozen impression of the branded numerals lasts for three to five minutes.

anol, and the cold iron was applied so that the entire face was in close contact with the skin. After branding, irons were immediately replaced in the supercold solution.

Once a system was established, no more than 3 minutes were needed to apply a 2-digit brand. Other work (castrating, vaccinating, dehorning) was done simultaneously and rarely conflicted with freeze branding.

Three groups of cattle were used in the study:

1. One hundred and thirty-six yearling steers and heifers were branded during November 1967. Irons were held against hide for 40 seconds.

2. Eighteen 2-year-old cows were branded in December 1967. Irons were held in place 40 seconds on six animals, 50 seconds on seven animals, and 60 seconds on the remaining five animals.

3. Forty-eight yearlings were branded during November 1968. Four groups of ten animals were branded 20, 30,40 , and 50 seconds, respectively. Eight additional animals were branded for 40 seconds while airtemperature methanol was dripped on the branding iron.

\section{Results and Discussion}

A frozen impression of the brand was visible on the skin for 3 to $5 \mathrm{~min}$ utes after the supercold iron was removed (Fig. 1). Within minutes after thawing, the brand became puffed and red (Fig. 2) and remained this way

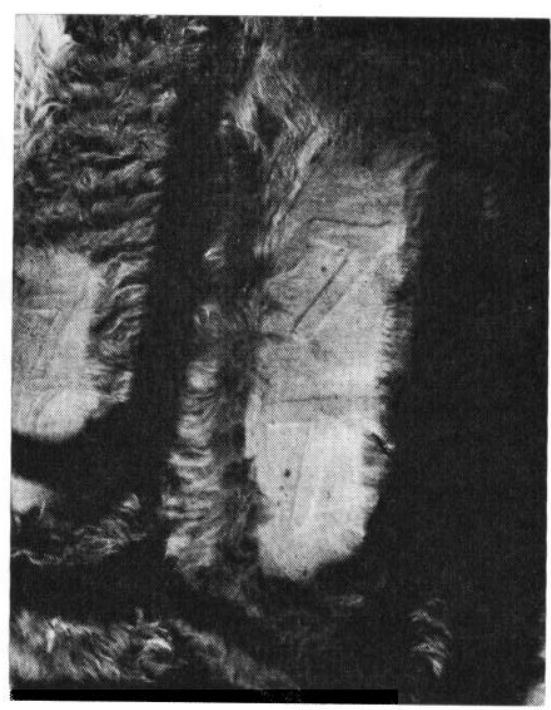

Fig. 2. After the brand thaws, the numerals are puffed and red for several days.

for several days. Some hair began to slip within 3 weeks, and the numerals somewhat resembled a hot brand. White hair first appeared within 2 to 3 months, but at least 4 months passed before the numerals were readily distinguishable to the eye (Fig. 3). More time was often necessary before brands could be read from Super-8 movie film.

On some individuals, brands did not turn white. Often the non-white-hair brands were discernible at close range because of a subtle difference in hair color. On other animals, white hair appeared on only part of the brand. Brands in either of these categories were useless for identification on Super-8 film.

Of the 136 yearlings branded in $1967,83 \%$ had readable, white-haired brands within 6 months. White hair was completely absent on $8 \%$.

All the 2-year-old cows branded for 40 or 60 seconds had white-haired, readable brands within 6 months after branding. Of those branded for 50 seconds, four had white-haired brands and three did not, although all brands were discernible at close range. Why three brands did not result in white hair is unknown.

All of 48 of the animals branded in 1968 had white-haired brands within 6 months after branding, although 12 of the brands were partial. All could be distinguished at close range. Length of branding time and application of alcohol while branding seemed to have little effect.

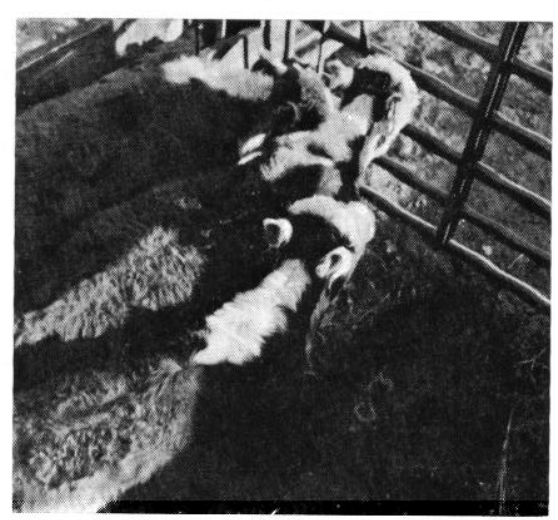

Fig. 3. The white-haired numerals are visible within three or four months after branding.

Although most brands from the 2year study were readable at close range, identification from Super-8 film was less than satisfactory. First, most brands could not be distinguished on film during the first 4 to 6 months. If yearlings or calves are used in a study, they must be branded at least 4 months prior to use. Second, animals crossed the scale platforms at all hours of the day, so that light and shadow conditions varied. Unless branding resulted in excellent numerals with much white hair, identification was often impossible from film. In this study, less than $60 \%$ of the animals could be identified from Super-8 film, even though well over $80 \%$ could be identified with the naked eye at similar range.

\section{Literature Cited}

Anonymous. 1970. Filling the blanks on freeze branding. Ariz. Cattlelog XXVI:37-38.

Ely, D. G., and J. L. Launchbaugh. 1969. Multiple iron holder for freeze branding. J. Range Manage. 22:135-137, illus.

Martin, S. Clark, Kenneth K. Barnes, AND LEONARD BASHFORd. 1967. A step toward automatic weighing of range cattle. J. Range Manage. 20: 91-94, illus.

\section{Longmont Seed Co.}

\author{
We Buy \& Sell Western Range Grass \\ \& Legume Seeds \\ CONFRONT US with your RANGE \\ PROBLEMS: phone: $303+776-1320$ \\ LONGMONT, COLORADO 80501
}

